\title{
Iberian Halophytes as Agroecological Solutions for Degraded Lands and Biosaline Agriculture
}

\author{
Bernardo Duarte $1,2, *$ (D) and Isabel Caçador 1,2 \\ 1 MARE-Marine and Environmental Sciences Centre, Faculdade de Ciências da Universidade de Lisboa, \\ Campo Grande, 1749-016 Lisbon, Portugal; micacador@fc.ul.pt \\ 2 Departamento de Biologia Vegetal, Faculdade de Ciências da Universidade de Lisboa, Campo Grande, \\ 1749-016 Lisbon, Portugal \\ * Correspondence: baduarte@fc.ul.pt
}

check for

updates

Citation: Duarte, B.; Caçador, I. Iberian Halophytes as Agroecological Solutions for Degraded Lands and Biosaline Agriculture. Sustainability 2021, 13, 1005. https://doi.org/ $10.3390 /$ su13021005

Academic Editor: David John Gibson Received: 28 October 2020

Accepted: 15 January 2021

Published: 19 January 2021

Publisher's Note: MDPI stays neutral with regard to jurisdictional claims in published maps and institutional affiliations.

Copyright: (c) 2021 by the authors. Licensee MDPI, Basel, Switzerland. This article is an open access article distributed under the terms and conditions of the Creative Commons Attribution (CC BY) license (https:/ / creativecommons.org/licenses/by/ $4.0 /)$.

\begin{abstract}
Research on biosaline agriculture has been increasing worldwide in recent years. In this respect, the Iberian halophyte diversity present a high-value ecological solution to be implemented for biosaline-based agroecosystems. The research on these halophytic species has been increasing worldwide and, in the recent years, especially in terms saline agriculture adaptation, osmophysiology and nutraceutical potential, highlighting the importance and potential of these species in terms of agrosolutions. The Mediterranean area has high biodiversity in terms of endemic halophytic vegetation (ca. 62 species), providing an alternative pool of potential new agricultural products to be cultivated in adverse conditions. Besides being highly diverse, most of these species are endemic and present a perennial life cycle with several applications in terms of food, forage, nutraceutical, feedstock and remediation. More specifically, the Iberian halophytic flora shows potential as resources of essential fatty acids, minerals and antioxidants-all very important for human and animal nutrition. Alongside the establishment of halophyte agroecological solutions is the provision of key ecosystem services, such as carbon sequestration and soil rehabilitation. Moreover, halophyte-based ecosystems provide additional recognized ecosystem services, beyond the final product production, by improving soil health, ecosystem biodiversity and storing large amounts of carbon, thereby increasing the ecosystem resilience to climate change and offering a green solution against climate change.
\end{abstract}

Keywords: biosaline agriculture; halophytes; agroecosystems; alternative cash crops

\section{Halophyte Sustainable Agriculture: An Emerging Topic}

Halophytes are defined as species that grow and complete their life cycle in environments with $\mathrm{NaCl}$ concentrations above $200 \mathrm{mM}$ [1]. The nutritional and nutraceutical value of halophytes has been widely explored in several countries in biosaline agricultural schemes [2-5]. These species have shown to be important healthy mineral sources, with several anti-oxidant compounds and essential nutrients for human consumption [2,3,6-8]. Among others, halophytes have shown to be a good source of anti-oxidant molecules [9], essential fatty acids [6,8], carotenoids and polysaccharides [10] and essential micronutrients [11]. As mentioned above, in the last decades, halophytes have been regarded as potential alternative sources for human consumption. The increasing global changes and reduction in freshwater resource availability have increased soil salinization and land degradation [12]. On the other hand, the human population is increasing at an unprecedented rate, with population growth estimations pointing out to an increase from 7.8 billion (2020) to 10.9 billion at the end of the century [13]. This fact inevitably increases the demand for food sources and, by 2050, it is estimated that crop production must increase by $70 \%$ to $100 \%$ to meet global food demand [14]. Considering the actual annual yield increase for major crops is estimated to be from $1 \%$ to $1.5 \%$, agricultural food sustainability is at risk [15]. It becomes clear that the combination of these demographic and climatic factors, especially in arid and semi-arid regions, are intrinsically connected and based on problems such as 
poverty, social insecurity and environmental refugee situations [16]. The transversal effects of these rapid changes and increasing food demand have led to an increase in scientific research in this area in both low- and high-income countries [17]. Some of the first studies on halophyte salinity tolerance and its potential application for saline agriculture and degraded lands go back to the 1970s [18]. This long-lasting research led to the formation of a group of experts on halophyte physiology and agriculture, gathered around a COST action (FA0901-Putting Halophytes to Work-From Genes to Ecosystems), which had as a major outcome the creation of the Institute of Sustainable Halophyte Utilization in Karachi, Pakistan. Another important outcome of this scientific group was the production of the eHaloph [19], a database of the world's halophytes, gathering information on plant type, life form, ecotypes, maximum salinity tolerated, the presence or absence of salt glands, photosynthetic pathway, antioxidants, secondary metabolites, compatible solutes, habitat, economic use and whether there are publications on their germination, microbial interactions and mycorrhizal status, bioremediation and molecular data [19]. This cooperation and increasing need to investigate these natural communities as a potential solution for human global needs led to an exponential increase in scientific research in this area worldwide (Figure 1). Although high-income countries lead the investigation on this subject, it is worth noticing the already high number of scientific outputs focusing on halophyte agriculture practices and applications in low-income countries.

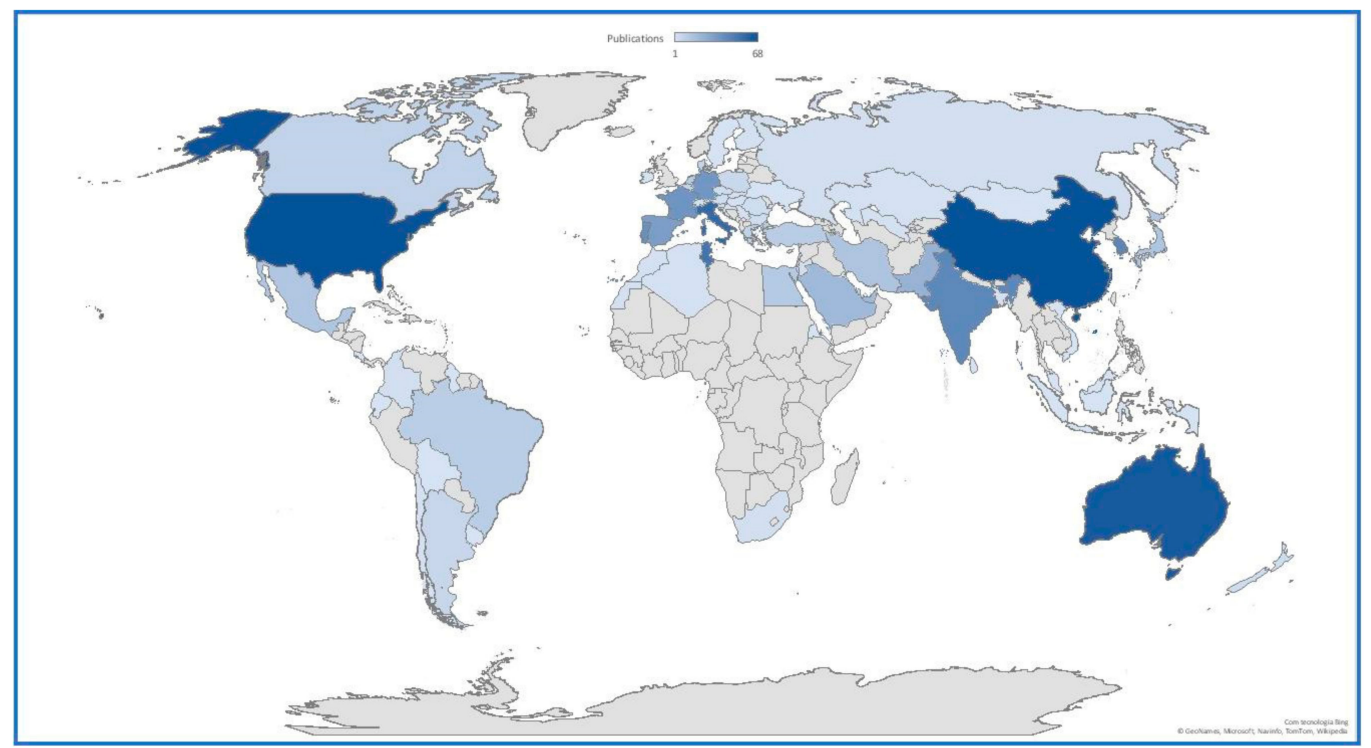

Figure 1. Worldwide distribution of the scientific production on halophyte agriculture, according to the Web of Science (search string: ALL FIELDS: (halophytes) AND ALL FIELDS: (food) OR TOPIC: (halophytes) AND TOPIC: (agriculture). Timespan: All years. Indexes: SCI-EXPANDED, SSCI, A\&HCI, CPCI-S, CPCI-SSH, ESCI, CCR-EXPANDED, IC.) core collection records from 1988 to the present day. Color bar intensity denotes the number of papers obtained using this search string, ranging from 1 (light blue) to 68 (dark blue).

It is also worth noticing the increasing collaboration between the leading countries and the less developed countries, aiming to produce scientific data to solve the food problems in these less developed countries (Figure 2). Again, this increasing collaboration reinforces the global interest on alternative and sustainable solutions for food production, which although more severely felt in low-income countries, have inevitable impacts worldwide. 


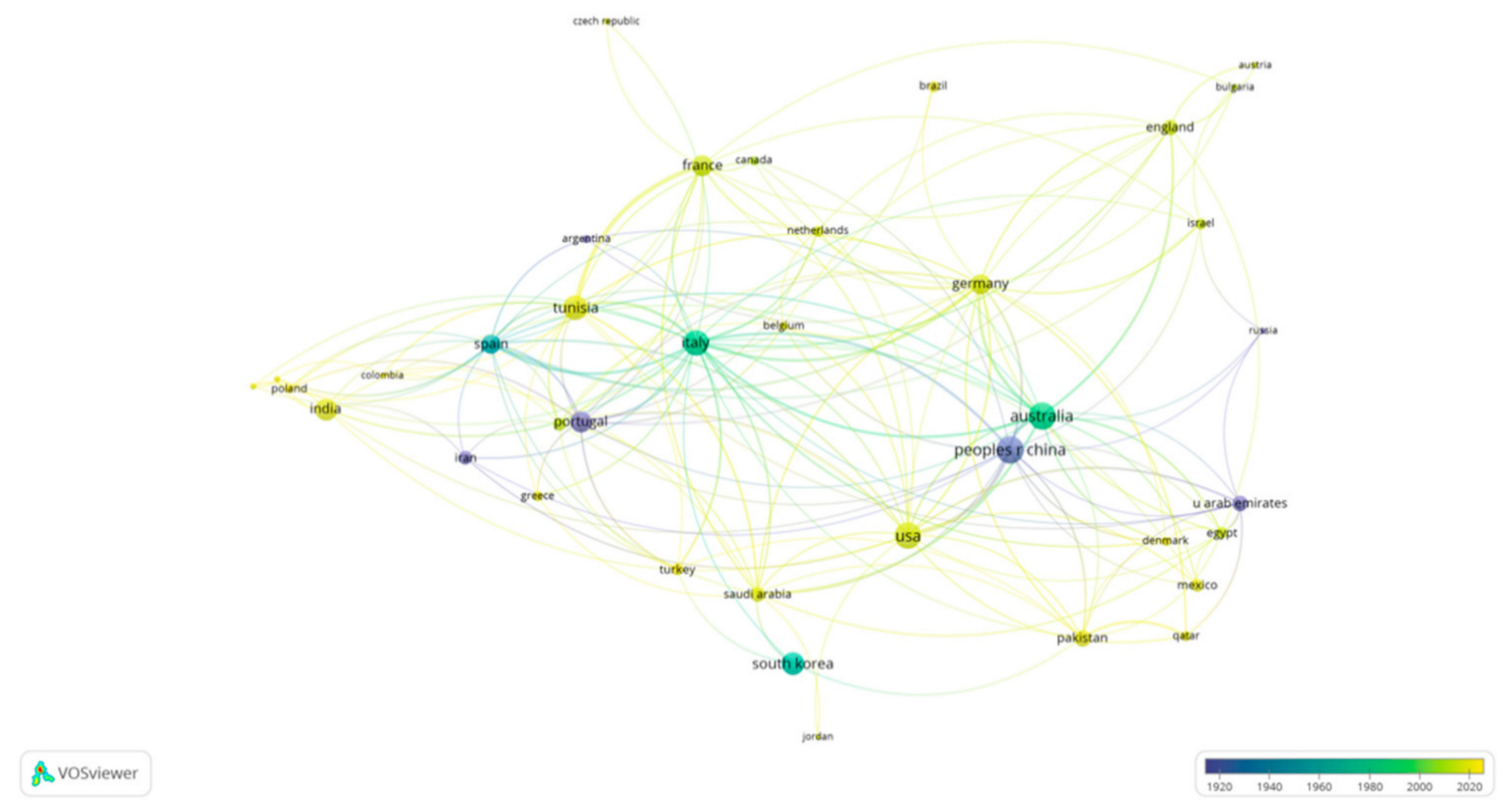

Figure 2. VOSviewer cluster analysis between the countries with a higher publication record, according to the Web of Science (search string: ALL FIELDS: (halophytes) AND ALL FIELDS: (food) OR TOPIC: (halophytes) AND TOPIC: (agriculture). Timespan: All years. Indexes: SCI-EXPANDED, SSCI, A\&HCI, CPCI-S, CPCI-SSH, ESCI, CCR-EXPANDED, IC.) records from 1988 to the present day.

These scientific records are now composed by approximately 566 scientific outputs that have increased exponentially in the last years (539 publications since the year 2000), in several scientific areas, ranging from Plant Sciences (31\%), Environmental Sciences (15\%), Food Science and Technology (13\%), Agronomy (12\%), Ecology (6\%), Soil Science (5\%), Applied Biotechnology (5\%), Biochemistry and Molecular Biology (5\%), Applied Chemistry $(4 \%)$ and Microbiology (3\%). Considering the applied sciences, it is noticeable that $34 \%$ of the total publications are found in this area, reinforcing that this agricultural and food sciences application is a priority area for the scientific community. In fact, and regarding the keyword distribution of this publication record, some clusters highlight the scientific objectives' distribution (Figure 3). Six major keyword clusters are evident. A first cluster (red cluster with 109 items) gathered publications with keywords focusing on metabolite research, with potential nutraceutical applications of the halophyte species for human consumptions. A second cluster (green cluster with 81 items) adds another dimension to halophyte cultivation, focusing mainly in the ecosystem services provided by these sustainable agricultural solutions in terms of ecosystem remediation and restoration and being biomass source for industrial applications. The third major cluster (dark blue cluster with 66 items) formed is composed of publications focusing on halophyte distribution, ecology, biogeography and domestication. The yellow cluster (gathering 55 items) represents the works focusing on the halophytes' osmophysiology and molecular basis and is composed of fundamental research publications. A fifth cluster (purple cluster composed by 52 items) is intrinsically connected with the latter cluster, clustering publications focusing on the biochemical basis of salt tolerance in halophytes. The last major cluster detected (light blue cluster composed by 46 items) is intrinsically connected with the last two clusters, gathering publications focusing on the metabolic changes that halophytes undergo and its comparison and application in glycophyte species. Although these groups can be distinguished in the clustering analysis, it is also evident in the intricate network of connections between the publication keywords, highlighting the application of the physiological, metabolic and molecular approaches, aiming for a more applied scientific perspective to 
develop biosaline agricultural and cultivation practices, to ultimately produce nutritionally valuable vegetable foods without disregarding the ecological services and importance of these species.

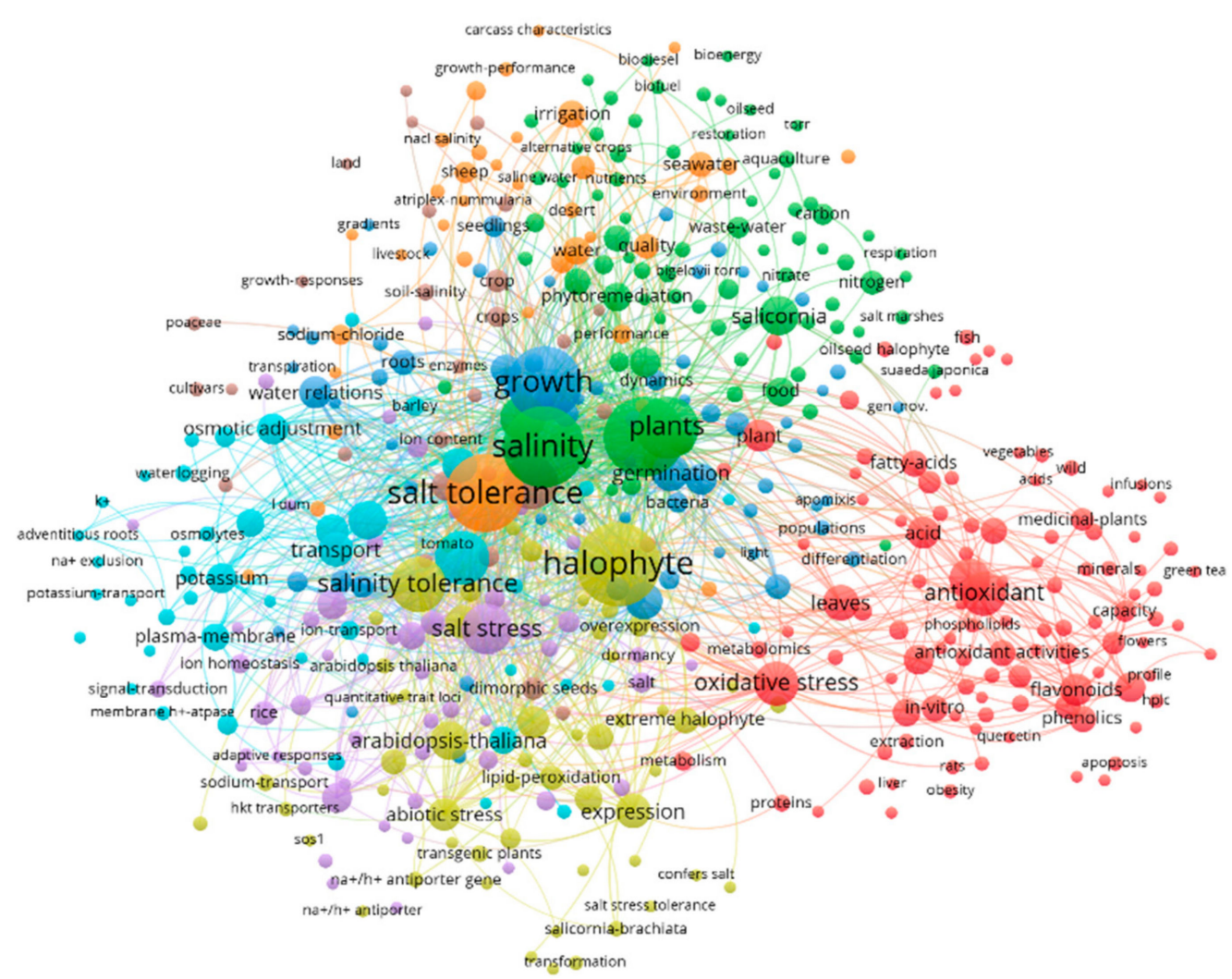

\& VOSviewer

Figure 3. VOSviewer cluster analysis between the keywords found in the Web of Science publication record (search string: ALL FIELDS: (halophytes) AND ALL FIELDS: (food) OR TOPIC: (halophytes) AND TOPIC: (agriculture). Timespan: All years. Indexes: SCI-EXPANDED, SSCI, A\&HCI, CPCI-S, CPCI-SSH, ESCI, CCR-EXPANDED, IC.) records from 1988 to the present day.

\section{Halophyte Ecology and Physiology}

If we consider halophytes as species that can thrive and tolerate at salinity concentrations of $80 \mathrm{mM}$ [20], the global halophyte plant community appears composed by more than 2600 species distributed on all the world's continents except Antarctica [20,21]. These comprise halophytes present in several types of ecosystems, ranging from salt deserts to mangroves, coastal dunes and salt marshes. The success of these plants in colonizing such different environments, from arid to flooded landscapes, results from their polyphyletic origin, and thus is a recent mechanism, such as the appearance of other complex traits such as the $\mathrm{C} 4$ and crassulacean acid metabolism photosynthesis pathways; this origin resulted in multiple and independent events where salt tolerance evolved in different angiosperm families [21]. This resulted in a multitude of physiological mechanisms, such as ion compartmentation, $\mathrm{K} / \mathrm{Na}$ selectivity, development of salt glands and production of osmocompatible solutes, among others, ultimately resulting in salt-tolerance traits [21]. Moreover, the ability of these plants to colonize both flooded and arid environments results from the same physiological tolerance basis. Both saline and desert environments induce osmotic stress in plants, and thus the basic mechanisms underlying tolerance to both conditions are the same $[8,22]$. As a trait, salt tolerance has been recognized for the past 200 years [21]. Nevertheless, this scientific area advanced greatly and thus the halophyte 
definition was revised and is now accepted as "plants that survive to complete their life cycle in at least $200 \mathrm{mM}$ salt" [1]; this group of plants was reduced down to 350 species, mainly from the order Caryophyllales (including the typical succulent chenopods) and Alismatales (including seagrasses) [21]. Based on these tolerance traits are several biochemical adaptations, especially in terms of specific molecules in response to the exposure to permanently stressful conditions, such as those observed in their natural habitats $[9,23,24]$. For example, fatty acid membrane remodeling is a common strategy of these species to overcome the osmotic stress imposed by the excessive salt concentrations observed in the sediments colonized by halophytes. Additionally, these species produce several anti-oxidant molecules (phenolics and flavonoids and ROS-quenching carotenoids) [25] to maintain cellular functioning under oxidative stress conditions, such as the ones triggered by high ionic contents and waterlogging and submersion [9,25]. Moreover, the exposure of high irradiances, to which these species are subjected in the Mediterranean, led these halophytes to develop carotenoid-based mechanisms to overcome this excessive sun-energy that reaches they photosynthetic organs $[9,25]$. All these physiological characteristics confer to halophytes remarkable nutritional characteristics, both in terms of an alternative sustainable food source for humans and also for animal feed.

In Europe, these species are mainly present in salt marsh ecosystems, occupying an area of approximately 451,652 ha, occurring in almost all estuarine, lagoon and bay ecosystem and providing an available living resource, spread almost all over the Atlantic and Mediterranean coasts $[26,27]$. Analyzing the species lists available in public databases for the Iberian Peninsula (https: / / flora-on.pt) and crossing this information with the data from the eHaloph database [19], regarding the physiological and application data of the Iberian halophytes, it becomes evident that this is a highly biodiverse pool of endemic plants with a large spectrum of applications (Table 1). The definition of halophyte was based in the presence of the species in eHaloph, and thus "Halophytes are defined as species that grow and complete their life cycle in environments with $\mathrm{NaCl}$ concentrations above $200 \mathrm{mM}^{\prime \prime}$ [1]. This list was cross listed with the coastal flora inventories and floristic data available from the Flora-on database and the species selected according to the presence in both databases.

Table 1. List of Iberian halophytes and their physiological and ecological traits and applications.

\begin{tabular}{|c|c|c|c|c|c|c|c|}
\hline Family & Species Name & $\begin{array}{l}\text { IUCN Con- } \\
\text { servation } \\
\text { Status }^{1}\end{array}$ & Origin $^{2}$ & $\begin{array}{l}\text { Photosynthetic } \\
\text { Metabolism }\end{array}$ & Life Cycle & $\begin{array}{c}\text { Raunkiær Life } \\
\text { Form }^{3}\end{array}$ & $\begin{array}{c}\text { Potential } \\
\text { Utilization }^{4}\end{array}$ \\
\hline Aizoaceae & Disphyma crassifolium & NE & NIS * & $\mathrm{C} 3$ & Perennial & $\mathrm{Ca}$ & $\mathrm{Fi}, \mathrm{O}, \mathrm{Br}$ \\
\hline Amaranthaceae & $\begin{array}{l}\text { Arthrocnemum } \\
\text { macrostachyum }\end{array}$ & NE & Native & $\mathrm{C} 3$ & Perennial & $\mathrm{Ca} /$ Hydro & M \\
\hline Amaranthaceae & Atriplex glauca & NE & Native & $\mathrm{C} 4$ & Perennial & $\mathrm{Ca}$ & $\mathrm{O}$ \\
\hline Amaranthaceae & Atriplex halimus & NE & Native & C4 & Perennial & $\mathrm{Ca} / \mathrm{Pha}$ & $\mathrm{Fo}, \mathrm{O}, \mathrm{Fr}, \mathrm{Br}, \mathrm{Fu}$ \\
\hline Amaranthaceae & Atriplex portulacoides & NE & Native & C3 & Perennial & $\mathrm{Ca} /$ Pha/Hydro & Fo, $\mathrm{Fr}, \mathrm{Br}$ \\
\hline Amaranthaceae & Salsola vermiculata & NE & Native & $\mathrm{C} 3$ & Perennial & $\mathrm{Ca}$ & \\
\hline Amaranthaceae & Halopeplis amplexicaulis & NE & Native & $\mathrm{C} 3$ & Perennial & $\mathrm{Te}$ & Fo, $\mathrm{M}$ \\
\hline Amaranthaceae & Sarcocornia fruticosa & NE & Native & C3 & Perennial & Ca/Pha/Hydro & Fo, $\mathrm{O}$ \\
\hline Amaranthaceae & Salicornia ramosissima & NE & Native & C3 & Annual & Te/Hydro & Fo \\
\hline Amaranthaceae & Salsola soda & NE & Native & $\mathrm{C} 4$ & Annual & Te/Hydro & Fo, D \\
\hline Amaranthaceae & $\begin{array}{l}\text { Sarcocornia perennis } \\
\text { subsp. alpini }\end{array}$ & NE & Native & $\mathrm{C} 3$ & Perennial & $\mathrm{Ca}$ & Fo, M \\
\hline Amaranthaceae & $\begin{array}{l}\text { Sarcocornia perennis } \\
\text { subsp. perennis }\end{array}$ & $\mathrm{NE}$ & Native & $\mathrm{C} 3$ & Perennial & $\mathrm{Ca} / \mathrm{Pha}$ & Fo, $\mathrm{M}$ \\
\hline Amaranthaceae & Suaeda maritima & NE & Native & $\mathrm{C} 3$ & Annual & Te/Hydro & Fo, D, M, Br \\
\hline Amaranthaceae & Suaeda splendens & NE & Native & $\mathrm{C} 4$ & Annual & $\mathrm{Te}$ & Fo, $\mathrm{Fr}$ \\
\hline Amaranthaceae & Suaeda vera & NE & Native & $\mathrm{C} 3$ & Annual & $\mathrm{Ca} /$ Pha/Hydro & Fo, D, S, O \\
\hline Amaranthaceae & Chenopodium album & NE & Native & C3 & Annual & $\mathrm{Te}$ & Fo, M \\
\hline Amaranthaceae & Atriplex patula & NE & Native & C3 & Annual & $\mathrm{Te}$ & $\mathrm{Fr}, \mathrm{Br}$ \\
\hline
\end{tabular}


Table 1. Cont.

\begin{tabular}{|c|c|c|c|c|c|c|c|}
\hline Family & Species Name & $\begin{array}{l}\text { IUCN Con- } \\
\text { servation } \\
\text { Status }^{1}\end{array}$ & Origin $^{2}$ & $\begin{array}{l}\text { Photosynthetic } \\
\text { Metabolism }\end{array}$ & Life Cycle & $\begin{array}{c}\text { Raunkiær Life } \\
\text { Form }^{3}\end{array}$ & $\begin{array}{c}\text { Potential } \\
\text { Utilization }\end{array}$ \\
\hline Amaranthaceae & Salicornia nitens & NE & Native & $\mathrm{C} 3$ & Annual & Hydro/Te & Fo \\
\hline Asteraceae & $\begin{array}{l}\text { Artemisia caerulescens } \\
\text { subsp. caerulescens }\end{array}$ & NE & Native & $\mathrm{C} 3$ & Perennial & $\mathrm{Ca}$ & \\
\hline Asteraceae & Aster squamatus & $\mathrm{NE}$ & NIS & C3 & Perennial & $\mathrm{Hem} / \mathrm{Te}$ & Fo \\
\hline Asteraceae & $\begin{array}{l}\text { Aster tripolium subsp. } \\
\text { pannonicus }\end{array}$ & $\mathrm{NE}$ & Native & $\mathrm{C} 3$ & Perennial & $\mathrm{He} / \mathrm{Te} / \mathrm{Hem}$ & $\mathrm{Fo}, \mathrm{M}, \mathrm{O}, \mathrm{Br}$ \\
\hline Asteraceae & Cotula coronopifolia & NE & NIS & $\mathrm{C} 3$ & Perennial & $\mathrm{Te}$ & $\mathrm{M}, \mathrm{O}$ \\
\hline Asteraceae & Inula crithmoides & NE & Native & $\mathrm{C} 3$ & Perennial & $\mathrm{Ca}$ & Fo, M, O \\
\hline Asteraceae & $\begin{array}{l}\text { Sonchus maritimus } \\
\text { subsp. maritimus }\end{array}$ & $\mathrm{NE}$ & Native & CAM & Perennial & Geo & $\mathrm{M}$ \\
\hline Boraginaceae & $\begin{array}{l}\text { Heliotropium } \\
\text { curassavicum }\end{array}$ & $\mathrm{NE}$ & Nis & $\mathrm{C} 4$ & Perennial & Hem & $\mathrm{B}, \mathrm{M}$ \\
\hline Caryophyllaceae & Spergularia australis & $\mathrm{NE}$ & Native & $\mathrm{C} 3$ & Annual & $\mathrm{Ca}$ & M \\
\hline Caryophyllaceae & Spergularia heldreichii & NE & Native & C3 & Annual & $\mathrm{Te}$ & \\
\hline Caryophyllaceae & Spergularia marina & NE & Native & C3 & Annual & $\mathrm{Hem} / \mathrm{Te}$ & M \\
\hline Caryophyllaceae & Spergularia media & NE & Native & $\mathrm{C} 3$ & Annual & $\mathrm{Ca} / \mathrm{He}$ & Fo \\
\hline Convolvulaceae & Cressa cretica & $\mathrm{NE}$ & Native & $\mathrm{C} 3$ & Perennial & $\mathrm{Te}$ & $\mathrm{C}, \mathrm{M}$ \\
\hline Cyperaceae & Bolboschoenus maritimus & NE & Native & $\mathrm{C} 3$ & Perennial & Geo & $\mathrm{B}, \mathrm{O}, \mathrm{Br}$ \\
\hline Cyperaceae & $\begin{array}{c}\text { Schoenoplectus lacustris } \\
\text { subsp. glaucus }\end{array}$ & $\mathrm{NE}$ & Native & C3 & Perennial & $\mathrm{He}$ & $\mathrm{O}$ \\
\hline Frankeniaceae & Frankenia boissieri & NE & Native & $\mathrm{C} 3$ & Perennial & $\mathrm{Ca}$ & $\mathrm{Fu}$ \\
\hline Frankeniaceae & Frankenia laevis & NE & Native & C3 & Perennial & $\mathrm{Ca}$ & $\mathrm{B}, \mathrm{O}$ \\
\hline Frankeniaceae & Frankenia pulverulenta & $\mathrm{NE}$ & Native & $\mathrm{C} 3$ & Perennial & $\mathrm{Te}$ & $\mathrm{O}$ \\
\hline Juncaceae & Juncus maritimus & $\mathrm{NE}$ & Native & C3 & Perennial & Hem & $\mathrm{Fe}, \mathrm{Fi}, \mathrm{Br}$ \\
\hline Juncaceae & Juncus effusus & $\mathrm{NE}$ & Native & C3 & Perennial & Hem & $\mathrm{Fe}, \mathrm{Fi}, \mathrm{Br}$ \\
\hline Juncaceae & Juncus acutus & $\mathrm{NE}$ & Native & $\mathrm{C} 3$ & Perennial & Hem & $\mathrm{Fe}, \mathrm{Fi}, \mathrm{Br}$ \\
\hline Juncaginaceae & Triglochin barrelieri & $\mathrm{NE}$ & Native & $\mathrm{C} 3$ & Perennial & $\mathrm{He} / \mathrm{Hem}$ & Fo \\
\hline Juncaginaceae & Triglochin maritimum & NE & Native & $\mathrm{C} 3$ & Perennial & $\mathrm{He} / \mathrm{Hem}$ & Fo \\
\hline Orobanchaceae & Cistanche phelypaea & $\mathrm{NE}$ & Native & $\mathrm{C} 3$ & Parasite & Epi/Geo & \\
\hline Plantaginaceae & Plantago macrorhiza & $\mathrm{NE}$ & Native & $\mathrm{C} 3$ & Perennial & $\mathrm{Ca}$ & M \\
\hline Plantaginaceae & $\begin{array}{c}\text { Plantago maritima subsp. } \\
\text { maritima }\end{array}$ & $\mathrm{NE}$ & Native & $\mathrm{C} 3$ & Perennial & Hem & $\mathrm{Fe}, \mathrm{M}$ \\
\hline Plumbaginaceae & $\begin{array}{l}\text { Armeria maritima subsp. } \\
\text { maritima }\end{array}$ & NE & Native & $\mathrm{C} 3$ & Perennial & $\mathrm{Ca}$ & $\mathrm{O}, \mathrm{Fr}, \mathrm{Br}$ \\
\hline Plumbaginaceae & $\begin{array}{l}\text { Limoniastrum } \\
\text { monopetalum }\end{array}$ & $\mathrm{NE}$ & Native & $\mathrm{C} 3$ & Perennial & Pha & $\mathrm{Fo}, \mathrm{M}, \mathrm{Br}$ \\
\hline Plumbaginaceae & Limonium diffusum & $\mathrm{EN}$ & Native & $\mathrm{C} 3$ & Perennial & $\mathrm{Ca}$ & Fo, M \\
\hline Plumbaginaceae & Limonium lanceolatum & $\mathrm{LC}$ & Native & C3 & Perennial & $\mathrm{Ca}$ & $\mathrm{M}$ \\
\hline Plumbaginaceae & Limonium ovalifolium & $\mathrm{NE}$ & Native & C3 & Perennial & $\mathrm{Ca}$ & Fo, M \\
\hline Plumbaginaceae & Limonium vulgare & NE & Native & $\mathrm{C} 3$ & Perennial & $\mathrm{Ca}$ & $\mathrm{M}, \mathrm{O}$ \\
\hline Plumbaginaceae & Limonium ferulaceum & $\mathrm{LC}$ & Native & $\mathrm{C} 3$ & Perennial & $\mathrm{Ca}$ & $\mathrm{O}$ \\
\hline Poaceae & Elymus athericus & NE & Native & C3 & Perennial & Proth & $\mathrm{M}$ \\
\hline Poaceae & Elymus elongatus & $\mathrm{NE}$ & Native & C3 & Perennial & Hem & $\mathrm{Fr}, \mathrm{Br}$ \\
\hline Poaceae & Parapholis filiformis & $\mathrm{NE}$ & Native & $\mathrm{C} 3$ & Perennial & $\mathrm{Te}$ & \\
\hline Poaceae & Parapholis incurva & $\mathrm{NE}$ & Native & $\mathrm{C} 3$ & Annual & $\mathrm{Te}$ & \\
\hline Poaceae & Puccinellia iberica & $\mathrm{NE}$ & Native & $\mathrm{C} 3$ & Perennial & Hem & \\
\hline Poaceae & Puccinellia maritima & $\mathrm{NE}$ & Native & $\mathrm{C} 3$ & Perennial & $\mathrm{He} / \mathrm{Hem}$ & $\mathrm{Fr}, \mathrm{Br}$ \\
\hline Poaceae & Spartina maritima & $\mathrm{NE}$ & Native & $\mathrm{C} 4$ & Perennial & Epi/Geo/Proth & $\mathrm{Fr}, \mathrm{Br}$ \\
\hline Poaceae & Spartina patens & $\mathrm{NE}$ & NIS & $\mathrm{C} 4$ & Perennial & Hydro & S, Fr \\
\hline Poaceae & Spartina densiflora & $\mathrm{NE}$ & NIS & $\mathrm{C} 4$ & Perennial & Hydro & $\mathrm{Fe}, \mathrm{Fi}, \mathrm{Fr}$ \\
\hline Polygonaceae & Polygonum equisetiforme & NE & Native & $\mathrm{C} 3$ & Perennial & $\mathrm{Ca}$ & $\mathrm{M}, \mathrm{O}$ \\
\hline Zosteraceae & Zostera marina & VU & Native & $\mathrm{C} 4$ & Perennial & Hydro & S \\
\hline Zosteraceae & Zostera noltii & NT & Native & $\mathrm{C} 4$ & Perennial & Hydro & \\
\hline
\end{tabular}

${ }^{1}$ Conservation status according to the International Union for Conservation of Nature: NE-Not Evaluated; LC—Least Concern; NT—Near Threatened; VU-Vulnerable; EN—Endangered; CR-Critically Endangered; EW-Extinct in the Wild; EX-Extinct.; ${ }^{2}$ According to the Flora-on database (https:// flora-on.pt); ${ }^{3} \mathrm{Ca}-$ Chamaephyte; Epi-Epiphyte; Pha-Phanerophyte; Geo-Geophyte; He-Helophyte; Hem-Hemiphyte; Hydro-Hydrophyte; Protho-Prothohemicriptophyte; Te-Therophytes; ${ }^{4}$ Based in eHaloph database; Fo-Food; Fe-Feedstock; C—Cosmetic; D—Detergent; S—Soil Stabilization; Fi—Fiber; B—Biocide; M-Medicinal; O—Ornamental; Fr—Forage; $\mathrm{Br}-$ Bioremediation; Fu—Fuel; * Non-indigenous species.

Half the halophyte species present in Iberian salt marsh ecosystems are from the Amaranthaceae, Asteraceae and Poaceae (Figure 4a), with the remaining species belonging to a wide variety of taxonomic families (Aizoaceae, Boraginaceae, Caryophyllaceae, Convolvulaceae, Cyperaceae, Frankeniaceae, Juncaceae, Juncaginaceae, Orobanchaceae, Plantaginaceae, Plumbaginaceae, 
Poaceae, Polygonaceae and Zosteraceae). From this, the majority of the species are endemic to the Iberian Peninsula, reinforcing the importance of this natural resource (Figure $4 b$ ). According to the Raunkiær system, the majority of these species are included in the classification of chamaephyte, therophyte, hydrophyte and hemiphyte (73\%) (Figure 4c). The vast majority of the species are perennial (77\%), increasing these species' potential as agronomic solutions, providing biomass throughout the year (Figure 4d).

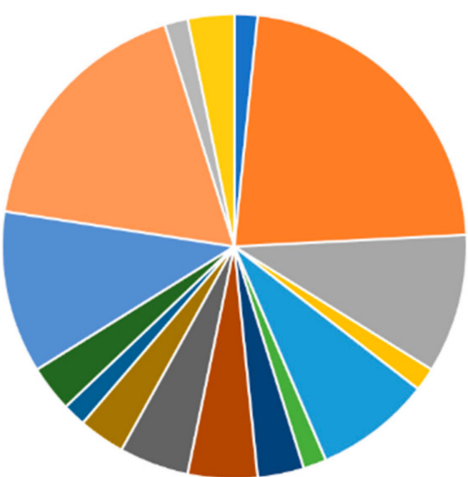

(a)

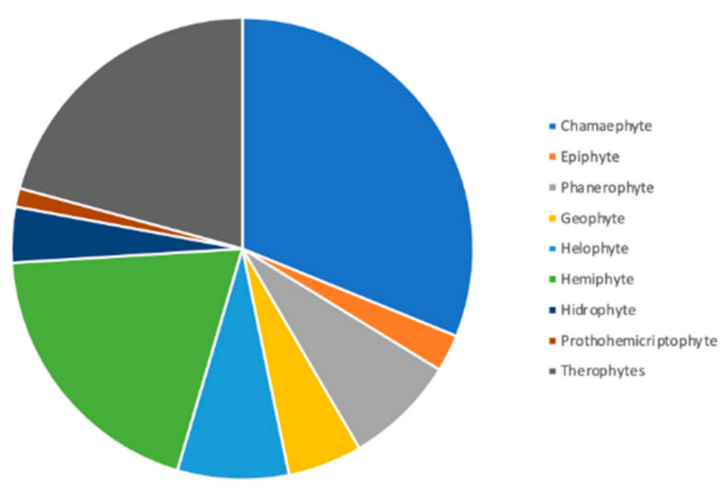

(c)

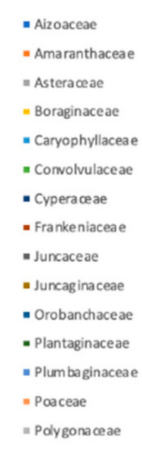

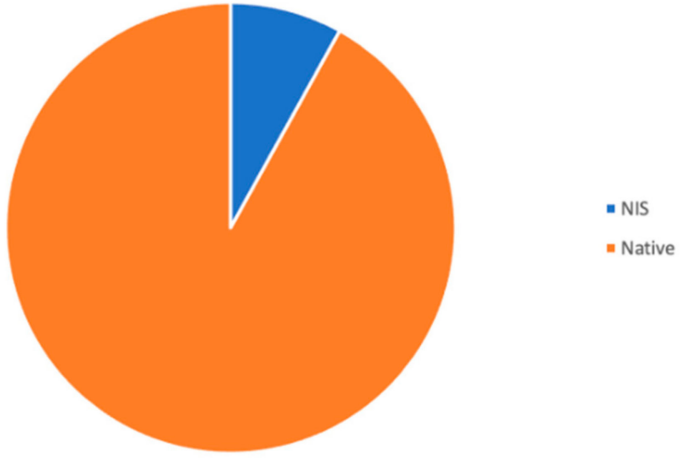

(b)

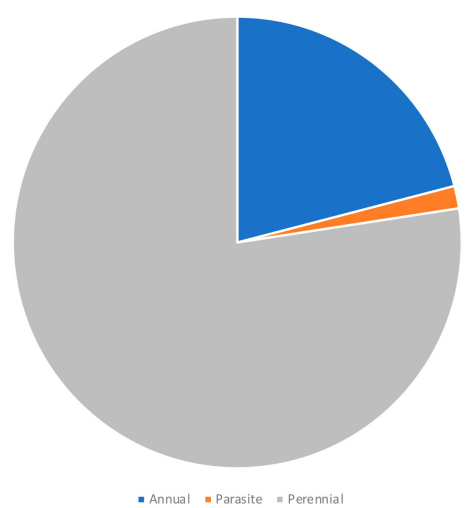

(d)

Figure 4. Iberian halophyte families (a); origin status (b) (non-indigenous species (NIS) and native species of the Iberian Peninsula); Raunkiær Life Form (c); and life cycle type (d).

\section{Economical Applications}

Halophytes are extremely versatile plants with a high tolerance to a wide range of adverse cultivation conditions $[8,15,25]$. Additionally, they have shown in the past to be important sources of nutrients for human consumption $[3,6,8]$. The Mediterranean area has high biodiversity in terms of endemic halophytic vegetation [28], providing a remarkable pool of potential new agricultural products to be cultivated in adverse conditions. In terms of utilizations, there is a wide array of possible uses of halophytes (Figure 5). 


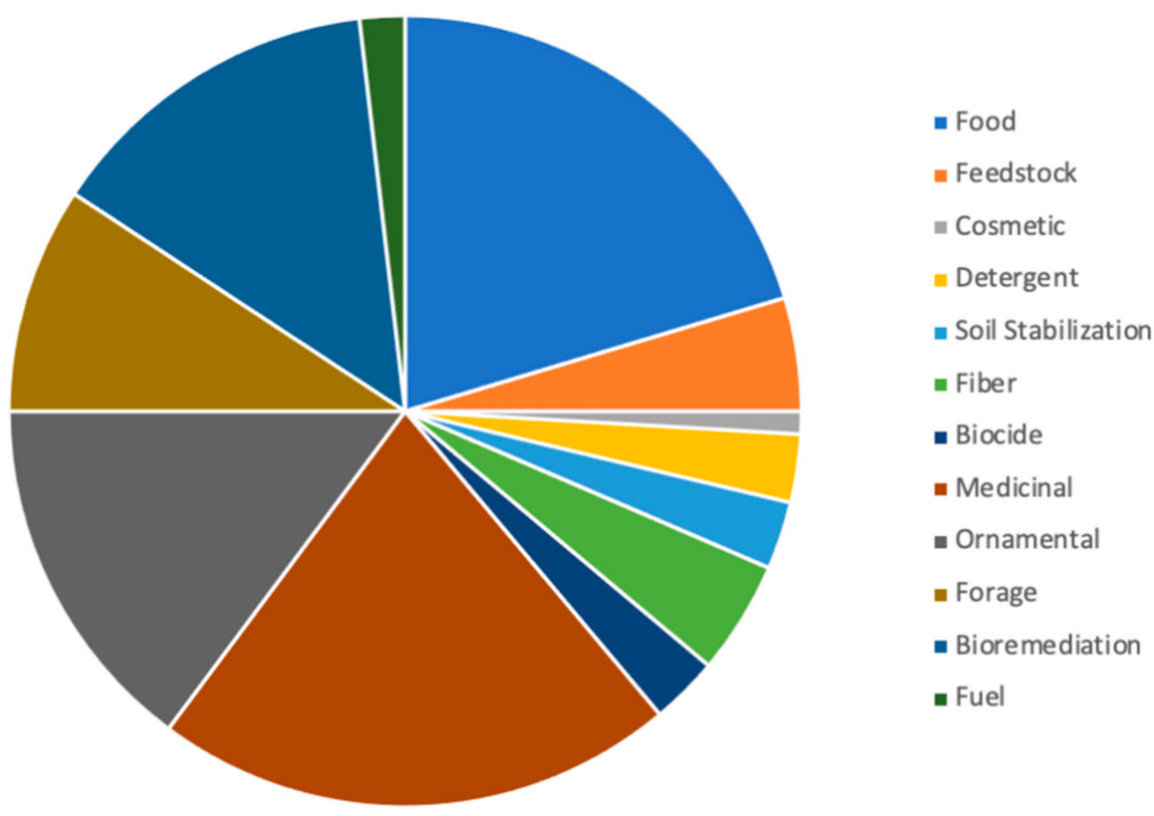

Figure 5. Potential utilization of the listed Iberian halophytes (source: eHaloph database).

Some species have been cultivated as food (alternative vegetables) and forage for animal consumption (20\% and $9 \%$ of the Iberian halophytes, respectively). Seeds are also one of the parts that have been explored in halophytes, as they do not generally accumulate salts in their seed, enhancing their potential for immediate use without additional treatment [29]. Although halophyte seeds are rather small, which could be seen as a disadvantage, this is largely surpassed by the relatively high yields per hectare [29]. Additionally, it is known that, in adapting to adverse conditions, plants suffer some lipid remodeling to maintain membrane stability and the efficiency of the metabolic processes associated with these systems [6]. Linolenic acid and linoleic acid are very abundant fatty acids in halophytes, being part of the omega- 3 and omega- 6 categories, respectively, and thus essential PUFAs for human health [6]. In this regard, S. fruticosa, A. tripolium, S. maritima and $S$. vera appear as some of the most promising Iberian halophytes, presenting very high PUFA/SFA and low n-6/n-3 PUFA ratios, suitable for potential applications in the food and/or feed industry [6,22,30-32]. Halophytes are also promising protein-rich food sources [33-35]. With the rapid growth in the world's population, food security is seen as one of the challenges for the agri-food industry. The shift towards a more sustainable diet necessitates less reliance on foods of animal origin, increasing the plant protein human intake [36]. If we take into account that to produce the same amount of plant proteins directly for human consumption, less than $10 \%$ of land will be required in comparison to animal production, adding to this the advantage that halophyte species can be cultivated in degraded lands, the potential of these marine plants increases greatly [37]. Some of the most abundant species in the Iberian Peninsula, such as H. portulacoides, S.maritima and S. fruticosa [29], show very high protein contents (up to $4 \mathrm{mg} \mathrm{g}^{-1} \mathrm{FW}$ ) in their edible parts [9]. During evolution, halophytes acquired a variety of adaptations to cope with an osmotically stressful environment, namely the production of osmocompatible solutes [38-40]. Among the production of several molecules, halophytes use sucrose, glucose and fructose to, among other functions, maintain its osmotic balance towards the external medium $[38,41]$. In developing countries, $50-75 \%$ of total dietary energy comes from carbohydrates (starch and sugars) and, quantitatively, starch is the most abundant (80$90 \%$ ) of all plant polysaccharides eaten [42]. Phenolic and flavonoid compounds are known as good radical scavengers, playing an important role in human health, by minimizing the deleterious effects of oxidative stress. Phenolic compounds, including flavonoids, are secondary metabolites that play different roles in the physiology and cellular mechanisms 
of plants, including pigmentation as well as resistance to pests, predators and oxidative stress. Halophytes live in extremely harsh environments, with high salinities and UV radiation, and these stressful conditions often lead to the production of radical oxygen species. Because they often display antioxidant properties, halophyte plants most likely produce phenolic compounds as additional components of their response to oxidative stress [43]. Previous studies with Iberian halophytes showed that these plants have an elevated concentration of total phenolics and flavonoids in their tissues [3,9], similar to those already used as anti-oxidant sources, such as M. crystallinum and M. nodiflorum [10,44,45]. Some other Iberian species' (P. maritima, S. maritima and S. patens) polyphenolic extracts have shown the relevant antioxidant, anti-acetylcholinesterase, antibacterial and antifungal activities, reinforcing the nutritional and medicinal potential of these halophytic grasses [46]. Although not documented, several species of halophytes, including Saliconia spp., Sarcocornia spp. (both sold as sea asparagus) and Aster tripolium (sea-spinach), are sold in Portuguese markets. There are no currently available statistics on the daily usage of these vegetables, but the growing number of enterprises selling these kind of vegetables indicate that there is also an increasing consumption and acceptance from the general public.

Independently of their high nutritional value, the success of halophytes as agroecological solutions as well as their commercial success in the near future will depend largely on consumer acceptance of new tastes and textures in their diet. At present, certain halophytes (like the sea aster $A$. tripolium) are being cultivated as vegetables, due to its morphological similarity with conventional vegetables that have a high degree of public acceptance (e.g., the sea aster is often commercialized as sea spinach).

Besides their role as essential fatty acid sources [32,47], halophytes seeds have also been considered for biofuel production [48]. In this regard, $2 \%$ of the Iberian halophytes have been described as potential sources for biofuel, produced from the seeds and the lignocellulosic biomass [29]. In this regard, A. tripolium and S. fruticosa seeds appear as good candidates for biofuel production, presenting a high triglycerides yield and rich in saturated fatty acids, the most adequate for biofuel production [6].

In the past, halophytic grasses, shrubs and trees, containing digestible protein levels comparable to conventional livestock feed, were planted as forage or harvested for fodder [49-51]. Despite their recent decline, forage and fodder supplements still account for the bulk of commercial halophyte cultivation around the world: these include grasses (like Puccinellia, Spartina and Sporobolus) and shrubs (Atriplex, Salsola and Suaeda) [49-51]. Due to the relatively high salt content in their tissue (between 10 and $50 \%$ of their dry weight), the potential is greatest when interplanted with native forage or used in mixed feeding regimes, such as a dry season browse and fodder supplement [52]. Many of these salt-tolerant plants have also demonstrated promise in the extraction and production of leaf protein concentrates that are being increasingly used in animal feeds [52].

As ornamentals, halophytes also provide an alternative solution. The cut flower industry is economically important in several countries; nevertheless, growers require high-quality water to irrigate cut flower crops [53]. Flowering and ornamental halophytes can grow using alternative water sources for irrigation (such as wastewaters) [53]. Several plant families contain halophytic species, which are potentially useful as cut flowers, e.g., Asteraceae (Inula spp.), Plumbaginaceae (Limonium spp.) and Portulacaceae (Portulaca spp.). The identification of halophytic species that are both salt-tolerant and have potential commercial relevance would permit the reuse of degraded, often saline wastewaters for floriculture production. Thus, this way the reuse of saline wastewaters provides a viable option for the irrigation of salt-tolerant floral crops, increasing the value of halophytic agroecosystems [53].

\section{Soil Remediation, Restoration and Ecosystem Services}

Halophytic polycultures for fuel, timber, and conservation offer an extremely valuable asset in the creation of sustainable agroforestry schemes, the stabilization and rehabilitation of degraded environments and the deceleration of deforestation and desertification [54]. The replanting of salt marsh ecosystems in estuarine coasts represents another immediate 
low-cost opportunity for both environmental restoration and sustainable commercial production.

Soil salinization affects approximately one billion hectares of land globally, affecting landscape components including landform, soil and plant communities [55]. Thus, the rehabilitation of salt-affected lands is necessary to make these ecosystems suitable to be reused for agricultural resources, such as grazing or production of traditional crops [55]. Land rehabilitation is also advantageous as it increases biodiversity and limits soil erosion and land degradation [55]. The tolerance to high saline concentrations exhibited by several halophytes makes these species suitable for rehabilitation of salinized soils. Arthrocnemum macrostachyum is a halophyte of great interest for desalinization purposes, but also as co-culture [56]. The presence of this species decreased the salinity of the soil by $31 \%$ after 30 days [56]. Additionally, when cultivated as a co-culture with barley and wheat, the halophyte presence reduced the negative effects of salt on the emergence of both barley and wheat [56].

Soil contamination with toxic compounds is additionally a major problem affecting soils worldwide, either due to industrial pollution or to agricultural misconducts [57]. The growing contamination by heavy metals in the environment leads to an increase in global risk to human and ecological health, resulting in the degradation or loss of some soil functions globally [57]. In this regard, several Iberian halophytes (e.g., H. portulacoides, Sarcocornia spp., S. maritima, J. accutus and S. ramosissima) have been investigated for its ability to remediate soil by extracting the heavy metals from soils to their aboveground organs and by improving the soils with organic acids and growth-promoting bacteria, beneficial for traditional crop establishment [58-63].

Landscape transformation due to agriculture impacts more than $40 \%$ of the planet's land area and is the most important driver of biodiversity and ecosystem services losses worldwide [64]. Ecological restoration through the establishment of agroecosystems may significantly reduce these losses and has shown to increase the overall biodiversity of all organism types by an average of $68 \%$ [64]. Previous works point out that agroecosystem ecological restoration is largely effective and can be advocated as a way to improve biodiversity and ecosystem services [64]. In terms of ecosystem services, halophyte-based agroecosystems would provide essential and similar services to that verified in natural salt marsh ecosystems. As a source of forage, reports show that these ecosystems can drive an annual net income from grazing of $£ 15.27 \mathrm{ha}^{-1}$ year $^{-1}$ [65]. Regarding their ability to remediate wastewater and wastelands, marsh swamps achieved capitalized cost savings of US $\$ 785$ to US $\$ 15,000 /$ acre compared to conventional municipal treatment [66]. If these agroecosystems are located in coastal areas and estuarine systems, they can additionally enhance side activities, such as fisheries, by boosting the production of economically important fishery species, such as shrimp, oysters, clams and fishes $[67,68]$. Reports from the Gulf Coast show that the contribution per acre of added salt marsh area to the value of the Gulf Coast blue crab fishery increases up to US\$1.89/acre [69]. Moreover, and considering the increasing climate change concerns and the demands for reducing the human carbon footprint, halophyte-based ecosystems play a very important role in terms of the so-called blue carbon storage [70]. These ecosystems are more effective carbon sinks (approximately $3.9 \mathrm{~kg} \mathrm{C} \mathrm{m}^{-2}$ year $^{-1}$ ), both in the short- and long-term storage of carbon, than typical terrestrial ecosystems, playing a critical role in the global sequestration of atmospheric carbon [70]. In a meter of topsoil, carbon storage in marsh ecosystems has been estimated at approximately $259 \mathrm{Mg}$ of carbon per hectare [70]. Using as reference the value of 2.1 Mg C/ha (permanent carbon sequestration) [71], and applying the Carbon Emission Reduction (CER) price of the European Emission Trading System (ETS) of $€ 12.38 / \mathrm{Mg}$, the estimated value of these agroecosystems in terms of carbon value could be estimated at $€ 26.00$ ha $^{-1}$ year $^{-1}$ [72]. Aside from the agronomical benefits obtained with the production of alternative halophytic crops, these ecosystem services highlight the relevance of these agroecosystems. 


\section{Conclusions}

Research on biosaline agriculture and halophyte-based ecosystems has been growing worldwide, focusing on their application in metabolite research, with potential nutraceutical applications; halophyte cultivation, focusing mainly on the ecosystem services in terms of ecosystem remediation and restoration and as a biomass source for industrial applications; halophyte distribution, ecology, biogeography and domestication; osmophysiology; and the biochemical basis of salt tolerance in halophytes, and its comparison to and application in glycophyte species. Iberian coastal areas present a wide diversity of halophytes species (62), being mostly endemic species, including some of the most investigated species worldwide. The wide range of applications of these species as food, forage and source of nutraceutical molecules, as well as for ornamental or bioremediation purposes, highlights the potential of this biodiversity bank for agroecosystem solutions. Allied to this is the widely recognized ecosystem values provided by halophyte-based environments, which increase the added-value of these ecosystems, beyond the final product production, by improving soil health, ecosystem biodiversity and storing large amounts of carbon, thereby increasing the ecosystem resilience to climate change and offering a green solution against climate change.

Author Contributions: Conceptualization, B.D. and I.C.; data curation, B.D.; writing—original draft preparation, B.D.; writing-review and editing, I.C.; project administration, B.D.; funding acquisition, B.D. All authors have read and agreed to the published version of the manuscript.

Funding: The authors would like to thank Fundação para a Ciência e a Tecnologia (FCT) for funding the research via the project grant UIDB/04292/2020. Work was also funded by MAR 2020 program via the Project RESTAURA2020 (16-01-04-FMP-0014). B. Duarte was supported by an FCT investigation contract (CEECIND/00511/2017).

Institutional Review Board Statement: Not applicable.

Informed Consent Statement: Not applicable.

Data Availability Statement: No new data were created or analyzed in this study. Data sharing is not applicable to this article.

Conflicts of Interest: The authors declare no conflict of interest.

\section{References}

1. Flowers, T.J.; Colmer, T.D. Salinity tolerance in halophytes. New Phytol. 2008, 179, 945-963. [CrossRef]

2. Ventura, Y.; Eshel, A.; Pasternak, D.; Sagi, M. The development of halophyte-based agriculture: Past and present. Ann. Bot. 2015, 115, 529-540. [CrossRef] [PubMed]

3. Barreira, L.; Resek, E.; Rodrigues, M.J.; Rocha, M.I.; Pereira, H.; Bandarra, N.; da Silva, M.M.; Varela, J.; Custódio, L. Halophytes: Gourmet food with nutritional health benefits? J. Food Compos. Anal. 2017, 59, 35-42. [CrossRef]

4. Abideen, Z.; Qasim, M.; Rizvi, R.F.; Gul, B.; Ansari, R.; Khan, M.A. Oilseed halophytes: A potential source of biodiesel using saline degraded lands. Biofuels 2015, 6, 241-248. [CrossRef]

5. Ben Hamed, K.; Ben Youssef, N.; Ranieri, A.; Zarrouk, M.; Abdelly, C. Changes in content and fatty acid profiles of total lipids and sulfolipids in the halophyte Crithmum maritimum under salt stress. J. Plant Physiol. 2005, 162, 599-602. [CrossRef]

6. Duarte, B.; Matos, A.R.; Marques, J.C.; Caçador, I. Lipids in halophytes: Stress physiology relevance and potential future applications. Halophytes Clim. Chang. Adapt. Mech. Potential Uses 2019, 359-371. [CrossRef]

7. Duarte, B.; Santos, D.; Marques, J.C.; Caçador, I. Ecophysiological adaptations of two halophytes to salt stress: Photosynthesis, PS II photochemistry and anti-oxidant feedback-Implications for resilience in climate change. Plant Physiol. Biochem. 2013, 67, 178-188. [CrossRef]

8. Duarte, B.; Cabrita, M.; Gameiro, C.; Matos, A.; Godinho, R.; Marques, J.C.; Caçador, I. Disentangling the photochemical salinity tolerance in Aster tripolium L.: Connecting biophysical traits with changes in fatty acid composition. Plant Biol. 2017, 19, 239-248. [CrossRef]

9. Duarte, B.; Santos, D.; Caçador, I. Halophyte anti-oxidant feedback seasonality in two salt marshes with different degrees of metal contamination: Search for an efficient biomarker. Funct. Plant Biol. 2013, 40, 922-930. [CrossRef]

10. Ksouri, R.; Ksouri, W.M.; Jallali, I.; Debez, A.; Magné, C.; Hiroko, I.; Abdelly, C. Medicinal halophytes: Potent source of health-promoting biomolecules with medical, nutraceutical and food applications. Crit. Rev. Biotechnol. 2012, 32, $289-326$. [CrossRef] 
11. Zurayk, R.A.; Baalbaki, R. Inula crithmoides: A candidate plant for saline agriculture. Arid Soil Res. Rehabil. 1996, 10, $213-223$. [CrossRef]

12. Okur, B.; Örçen, N. Chapter 12-Soil salinization and climate change. In Climate Change and Soil Interactions; Prasad, M.N.V., Pietrzykowski, M., Eds.; Elsevier: Amsterdam, The Netherlands, 2020; pp. 331-350. ISBN 978-0-12-818032-7.

13. United Nations. World Population Prospects 2019; United Nations: New York, NY, USA, 2019; ISBN 9789211483161.

14. World Bank. World Development Report 2008: Agriculture for Development; The World Bank: Washington, DC, USA, 2007.

15. Nikalje, G.C.; Srivastava, A.K.; Pandey, G.K.; Suprasanna, P. Halophytes in biosaline agriculture: Mechanism, utilization, and value addition. Land Degrad. Dev. 2018, 29, 1081-1095. [CrossRef]

16. Koyro, H.; Khan, M.A.; Lieth, H. Halophytic crops: A resource for the future to reduce the water crisis? Emir. J. Food Agric. 2011, 23, 1-16. [CrossRef]

17. Ismail, S.; Rao, N.K.; Dagar, J.C. Identification, Evaluation, and Domestication of Alternative Crops for Saline Environments. In Research Developments in Saline Agriculture; Dagar, J.C., Yadav, R.K., Sharma, P.C., Eds.; Springer: Singapore, 2019 ; pp. 505-536. ISBN 978-981-13-5832-6.

18. Poljakoff-Mayber, A.; Gale, J. (Eds.) Plants in Saline Environments; Springer: Berlin/Heidelberg, Germany, 1975; ISBN 978-3-64280931-6.

19. Santos, J.; Al-Azzawi, M.; Aronson, J.; Flowers, T.J. eHALOPH a database of salt-tolerant plants: Helping put halophytes to work. Plant Cell Physiol. 2016, 57, e10. [CrossRef] [PubMed]

20. O'Leary, J.W.; Glenn, E.P. Global distribution and potential for halophytes. In Halophytes as a Resource for Livestock and for Rehabilitation of Degraded Lands; Squires, V.R., Ayoub, A.T., Eds.; Springer: Dordrecht, The Netherlands, 1994; pp. 7-17. ISBN 978-94-011-0818-8.

21. Flowers, T.J.; Galal, H.K.; Bromham, L. Evolution of halophytes: Multiple origins of salt tolerance in land plants. Funct. Plant Biol. 2010, 37, 604-612. [CrossRef]

22. Duarte, B.; Matos, A.R.; Caçador, I. Photobiological and lipidic responses reveal the drought tolerance of Aster tripolium cultivated under severe and moderate drought: Perspectives for arid agriculture in the mediterranean. Plant Physiol. Biochem. 2020, 154, 304-315. [CrossRef]

23. Duarte, B.; Carreiras, J.; Pérez-Romero, J.A.; Mateos-Naranjo, E.; Redondo-Gómez, S.; Matos, A.R.; Marques, J.C.; Caçador, I. Halophyte fatty acids as biomarkers of anthropogenic-driven contamination in Mediterranean marshes: Sentinel species survey and development of an integrated biomarker response (IBR) index. Ecol. Indic. 2018, 87, 86-96. [CrossRef]

24. Carreiras, J.; Alberto Pérez-Romero, J.; Mateos-Naranjo, E.; Redondo-Gómez, S.; Rita Matos, A.; Caçador, I.; Duarte, B. The effect of heavy metal contamination pre-conditioning in the heat stress tolerance of native and invasive Mediterranean halophytes. Ecol. Indic. 2020, 111, 106045. [CrossRef]

25. Duarte, B.; Sleimi, N.; Cagador, I.; Caçador, I.; Cagador, I.; Caçador, I. Biophysical and biochemical constraints imposed by salt stress: Learning from halophytes. Front. Plant Sci. 2014, 5, 1-10. [CrossRef]

26. Mcowen, C.J.; Weatherdon, L.V.; Van Bochove, J.W.; Sullivan, E.; Blyth, S.; Zockler, C.; Stanwell-Smith, D.; Kingston, N.; Martin, C.S.; Spalding, M.; et al. A global map of saltmarshes. Biodivers. Data J. 2017, 5, e11764. [CrossRef]

27. Caçador, I.; Caetano, M.; Duarte, B.; Vale, C. Stock and losses of trace metals from salt marsh plants. Mar. Environ. Res. 2009, 67, 75-82. [CrossRef] [PubMed]

28. Caçador, I.; Neto, J.M.M.; Duarte, B.; Barroso, D.V.V.; Pinto, M.; Marques, J.C.C. Development of an Angiosperm Quality Assessment Index (AQuA-Index) for ecological quality evaluation of Portuguese water bodies-A multi-metric approach. Ecol. Indic. 2013, 25, 141-148. [CrossRef]

29. Sharma, R.; Wungrampha, S.; Singh, V.; Pareek, A.; Sharma, M.K. Halophytes as bioenergy crops. Front. Plant Sci. 2016, 7, 1372. [CrossRef] [PubMed]

30. Duarte, B.; Matos, A.R.; Marques, J.C.; Caçador, I. Leaf fatty acid remodeling in the salt-excreting halophytic grass Spartina patens along a salinity gradient. Plant Physiol. Biochem. 2018, 124, 112-116. [CrossRef] [PubMed]

31. Duarte, B.; Caçador, I.; Matos, A.R. Lipid landscape remodelling in Sarcocornia fruticosa green and red physiotypes. Plant Physiol. Biochem. 2020, 157, 128-137. [CrossRef]

32. Vizetto-Duarte, C.; Figueiredo, F.; Rodrigues, M.J.; Polo, C.; Rešek, E.; Custódio, L. Sustainable valorization of halophytes from the mediterranean area: A comprehensive evaluation of their fatty acid profile and implications for human and animal nutrition. Sustainability 2019, 11, 2197. [CrossRef]

33. Glenn, E.P.; O'Leary, J.W.; Watson, M.C.; Thompson, T.L.; Kuehl, R.O. Salicornia bigelovii Torr.: An Oilseed Halophyte for Seawater Irrigation. Science 1991, 251, 1065-1067. [CrossRef]

34. He, Z.; Ruan, C.; Qin, P.; Seliskar, D.M.; Gallagher, J.L. Kosteletzkya virginica, a halophytic species with potential for agroecotechnology in Jiangsu Province, China. Ecol. Eng. 2003, 21, 271-276. [CrossRef]

35. Marcone, M.F. Batis maritima (Saltwort/Beachwort): A nutritious, halophytic, seed bearings, perennial shrub for cultivation and recovery of otherwise unproductive agricultural land affected by salinity. Food Res. Int. 2003, 36, 123-130. [CrossRef]

36. Aiking, H. Future protein supply. Trends Food Sci. Technol. 2011, 22, 112-120. [CrossRef]

37. De Boer, J.; Aiking, H. On the merits of plant-based proteins for global food security: Marrying macro and micro perspectives. Ecol. Econ. 2011, 70, 1259-1265. [CrossRef] 
38. Slama, I.; Ghnaya, T.; Messedi, D.; Hessini, K.; Labidi, N.; Savoure, A.; Abdelly, C. Effect of sodium chloride on the response of the halophyte species Sesuvium portulacastrum grown in mannitol-induced water stress. J. Plant Res. 2007, 120, 291-299. [CrossRef] [PubMed]

39. Duarte, B.; Santos, D.; Silva, H.; Marques, J.C.; Caçador, I. Photochemical and biophysical feedbacks of $C_{3}$ and $C_{4}$ Mediterranean halophytes to atmospheric $\mathrm{CO}_{2}$ enrichment confirmed by their stable isotope signatures. Plant Physiol. Biochem. 2014, 80, 10-22. [CrossRef] [PubMed]

40. Duarte, B.; Santos, D.; Marques, J.C.C.; Caçador, I. Ecophysiological constraints of two invasive plant species under a saline gradient: Halophytes versus glycophytes. Estuar. Coast. Shelf Sci. 2015, 167, 154-165. [CrossRef]

41. Hajibagheri, M.; Flowers, T. Salt tolerance in the halophyte Suaeda maritima (L.) Dum. The influence of the salinity of the culture solution on leaf starch and phosphate content. Plant. Cell Environ. 1985, 8, 261-267.

42. Sánchez-Castillo, C.P.; Dewey, P.J.S.; Lara, J.J.; Henderson, D.L.; De Lourdes Solano, M.; James, W.P.T. The starch and sugar content of some mexican cereals, cereal products, pulses, snack foods, fruits and vegetables. J. Food Compos. Anal. 2000, 13, 157-170. [CrossRef]

43. Ksouri, R.; Megdiche, W.; Falleh, H.; Trabelsi, N.; Boulaaba, M.; Smaoui, A.; Abdelly, C. Influence of biological, environmental and technical factors on phenolic content and antioxidant activities of Tunisian halophytes. Comptes Rendus Biol. 2008, 331, 865-873. [CrossRef]

44. Essaidi, I.; Brahmi, Z.; Snoussi, A.; Ben Haj Koubaier, H.; Casabianca, H.; Abe, N.; El Omri, A.; Chaabouni, M.M.; Bouzouita, N. Phytochemical investigation of Tunisian Salicornia herbacea L., antioxidant, antimicrobial and cytochrome P450 (CYPs) inhibitory activities of its methanol extract. Food Control 2013, 32, 125-133. [CrossRef]

45. Gargouri, M.; Magné, C.; Dauvergne, X.; Ksouri, R.; El Feki, A.; Metges, M.A.G.; Talarmin, H. Cytoprotective and antioxidant effects of the edible halophyte Sarcocornia perennis L. (swampfire) against lead-induced toxicity in renal cells. Ecotoxicol. Environ. Saf. 2013, 95, 44-51. [CrossRef]

46. Faustino, M.V.; Faustino, M.A.F.; Silva, H.; Cunha, Â.; Silva, A.M.S.; Pinto, D.C.G.A. Puccinellia maritima, Spartina maritime, and Spartina patens Halophytic Grasses: Characterization of polyphenolic and chlorophyll profiles and evaluation of their biological activities. Molecules 2019, 24, 3796. [CrossRef]

47. Weber, D.J.; Ansari, R.; Gul, B.; Ajmal Khan, M. Potential of halophytes as source of edible oil. J. Arid Environ. 2007, 68, 315-321. [CrossRef]

48. Kosolapov, V.M.; Shamsutdinov, Z.S.; Shamsutdinova, E.Z.; Natirov, A.K.; Shamsutdinov, N.Z.; Shagaipov, M.M. Halophytes are promising sources for producing biofuel. Russ. Agric. Sci. 2016, 42, 242-245. [CrossRef]

49. El Shaer, H.M.; Gihad, E.A. Halophytes as animal feeds in Egyptian deserts. In Halophytes as a Resource for Livestock and for Rehabilitation of Degraded Lands; Squires, V.R., Ayoub, A.T., Eds.; Springer: Dordrecht, The Netherlands, 1994; pp. 281-284. ISBN 978-94-011-0818-8.

50. El Shaer, H.M.; Al Dakheel, A.J. Sustainable Diversity of Salt-Tolerant Fodder Crop-Livestock Production System Through Utilization of Saline Natural Resources: Egypt Case Study. In Halophytes for Food Security in Dry Lands; Khan, M.A., Ozturk, M., Gul, B., Ahmed, M.Z., Eds.; Academic Press: San Diego, CA, USA, 2016; pp. 177-195. ISBN 978-0-12-801854-5.

51. Masters, D.G.; Norman, H.C. Genetic and Environmental Management of Halophytes for Improved Livestock Production. In Halophytes for Food Security in Dry Lands; Khan, M.A., Ozturk, M., Gul, B., Ahmed, M.Z., Eds.; Academic Press: San Diego, CA, USA, 2016; pp. 243-257. ISBN 978-0-12-801854-5.

52. Attia-Ismail, S.A. New Perspectives in Forage Crops; Edvan, R.L., Bezerra, L.R., Eds.; InTech: London, UK, 2018; ISBN 978-953-513721-4.

53. Carter, C.T.; Grieve, C.M. Salt Tolerance Of Floriculture Crops. In Proceedings of the Ecophysiology of High Salinity Tolerant Plants; Khan, M.A., Weber, D.J., Eds.; Springer: Dordrecht, The Netherlands, 2006; pp. 279-287.

54. Khan, M.A.; Ansari, R. Potential use of halophytes with emphasis on fodder production in coastal areas of Pakistan. In Proceedings of the Biosaline Agriculture and High Salinity Tolerance; Abdelly, C., Öztürk, M., Ashraf, M., Grignon, C., Eds.; Birkhäuser: Basel, Switzerland, 2008; pp. 157-162.

55. Shaygan, M.; Mulligan, D.; Baumgartl, T. The potential of three halophytes (Tecticornia pergranulata, Sclerolaena longicuspis, and Frankenia serpyllifolia) for the rehabilitation of brine-affected soils. Land Degrad. Dev. 2018, 29, 2002-2014. [CrossRef]

56. Barcia-Piedras, J.M.; Pérez-Romero, J.A.; Mateos-Naranjo, E.; Camacho, M.; Redondo-Gómez, S. Effect of prior salt experience on desalination capacity of the halophyte Arthrocnemum macrostachyum. Desalination 2019, 463, 50-54. [CrossRef]

57. Weissmannová, H.D.; Pavlovský, J. Indices of soil contamination by heavy metals-Methodology of calculation for pollution assessment (minireview). Environ. Monit. Assess. 2017, 189. [CrossRef] [PubMed]

58. Duarte, B.; Caetano, M.; Almeida, P.R.R.; Vale, C.; Caçador, I. Accumulation and biological cycling of heavy metal in four salt marsh species, from Tagus estuary (Portugal). Environ. Pollut. 2010, 158, 1661-1668. [CrossRef]

59. Mesa-Marín, J.; Pérez-Romero, J.A.; Redondo-Gómez, S.; Pajuelo, E.; Rodríguez-Llorente, I.D.; Mateos-Naranjo, E. Impact of Plant Growth Promoting Bacteria on Salicornia ramosissima Ecophysiology and Heavy Metal Phytoremediation Capacity in Estuarine Soils. Front. Microbiol. 2020, 11, 1-12. [CrossRef]

60. Santos, D.; Duarte, B.; Caçador, I. Unveiling Zn hyperaccumulation in Juncus acutus: Implications on the electronic energy fluxes and on oxidative stress with emphasis on non-functional Zn-chlorophylls. J. Photochem. Photobiol. B Biol. 2014, 140, 228-239. [CrossRef] 
61. Redondo-Gómez, S. Bioaccumulation of heavy metals in Spartina. Funct. Plant Biol. 2013, 40, 913-921. [CrossRef]

62. Duarte, B.; Delgado, M.; Caçador, I. The role of citric acid in cadmium and nickel uptake and translocation, in Halimione portulacoides. Chemosphere 2007, 69, 836-840. [CrossRef]

63. Duarte, B.; Freitas, J.; Caçador, I. The role of organic acids in assisted phytoremediation processes of salt marsh sediments. Hydrobiologia 2011, 674, 169-177. [CrossRef]

64. Barral, M.P.; Rey Benayas, J.M.; Meli, P.; Maceira, N.O. Quantifying the impacts of ecological restoration on biodiversity and ecosystem services in agroecosystems: A global meta-analysis. Agric. Ecosyst. Environ. 2015, 202, 223-231. [CrossRef]

65. King, S.E.; Lester, J.N. The value of salt marsh as a sea defence. Mar. Pollut. Bull. 1995, 30, 180-189. [CrossRef]

66. Breaux, A.; Farber, S.; Day, J. Using natural coastal wetlands systems for wastewater treatment: An economic benefit analysis. J. Environ. Manag. 1995, 44, 285-291. [CrossRef]

67. Boesch, D.F.; Turner, R.E. Dependence of fishery species on salt marshes: The role of food and refuge. Estuaries 1984, 7, 460-468. [CrossRef]

68. MacKenzie, R.A.; Dionne, M. Habitat heterogeneity: Importance of salt marsh pools and high marsh surfaces to fish production in two Gulf of Maine salt marshes. Mar. Ecol. Prog. Ser. 2008, 368, 217-230. [CrossRef]

69. Freeman, A.M. Valuing environmental resources under alternative management regimes. Ecol. Econ. 1991, 3, 247-256. [CrossRef]

70. Himes-Cornell, A.; Pendleton, L.; Atiyah, P. Valuing ecosystem services from blue forests: A systematic review of the valuation of salt marshes, sea grass beds and mangrove forests. Ecosyst. Serv. 2018, 30, 36-48. [CrossRef]

71. Chmura, G.L.; Anisfeld, S.C.; Cahoon, D.R.; Lynch, J.C. Global carbon sequestration in tidal, saline wetland soils. Glob. Biogeochem. Cycles 2003, 17. [CrossRef]

72. Barbier, E.B.; Hacker, S.D.; Kennedy, C.; Koch, E.W.; Stier, A.C.; Silliman, B.R. The value of estuarine and coastal ecosystem services. Ecol. Monogr. 2011, 81, 169-193. [CrossRef] 